\title{
Corporate Disclosure melalui Media Sosial untuk Mengurangi Asimetri Informasi
}

\author{
Sila Ninin Wisnantiasri ${ }^{1 *}$, Putri Mutira ${ }^{2}$ \\ ${ }^{1}$ Program Studi Akuntansi, Universitas Pembangunan Jaya, Tangerang Selatan, Banten 15413, Indonesia \\ sila.wisnantiasri@upj.ac.id \\ ${ }^{2}$ Program Studi Akuntansi, Universitas Pembangunan Jaya, Tangerang Selatan, Banten 15413, Indonesia \\ putri.mutira@upj.ac.id
}

Received 17 December 2019, Revised 21 December 2019, Accepted 26 March 2020

\begin{abstract}
This study aims to determine whether corporate disclosure through corporate social media that possibly useful for investor decision making can reduce the information asymmetry between investors. We used a quantitative method and a purposive sampling technique with Consumer Goods Industry companies listed on the Indonesia Stock Exchange in 2018 as a sample. This industry sector was chosen because it was expected to have stronger predictions when consumers are retail consumers compared to business consumers. This study examines whether disclosure of information through social media such as Facebook and Twitter-owned by the company can reduce information asymmetry. Both of these social media platforms were chosen because they are widely used by the people of Indonesia. By using multiple regression analysis techniques, a surprising result is obtained where social media that have a significant effect on information asymmetry is Facebook, while social media Twitter does not have a significant effect on information asymmetry.
\end{abstract}

Keywords: Corporate Disclosure, Social Media, Information Asymmetry

\begin{abstract}
Abstrak - Penelitian ini bertujuan untuk mengetahui apakah pengungkapan informasi perusahaan (corporate disclosure) yang berguna untuk pengambilan keputusan investor melalui media sosial perusahaan dapat mengurangi asimetri informasi. Metode yang digunakan dalam penelitian ini adalah kuantitatif dengan teknik pengambilan sampel purposive sampling dengan sampel perusahaan Consumer Goods Industry yang terdaftar di Bursa Efek Indonesia pada periode 2018. Sektor industri ini dipilih karena diduga akan menghasilkan prediksi yang lebih kuat konsumennya adalah retail dibandingkan dengan konsumen bisnis. Penelitian ini menguji apakah pengungkapan informasi melalui media sosial seperti Facebook dan Twitter yang dimiliki perusahaan mampu menurunkan asimetri informasi. Kedua platform media sosial tersebut dipilih karena banyak digunakan oleh masyarakat Indonesia. Dengan menggunakan teknik analisis regresi berganda, diperoleh hasil yang mengejutkan dimana media sosial yang berpengaruh signifikan pada asimetri informasi adalah Facebook, sedangkan media sosial Twitter tidak memiliki pengaruh yang signifikan terhadap asimetri informasi..
\end{abstract}

Kata Kunci: Corporate disclosure, Media sosial, Asimetri informasi

\section{PENDAHULUAN}

Pada era revolusi industri 4.0, Internet berperan penting dalam akselerasi penyampaian informasi perusahaan kepada investor yang sering disebut sebagai corporate disclosure. Saluran informasi yang bisa dilakukan yaitu pengungkapan informasi melalui pemberitaan publik dari business press (Drake, Guest dan Twedt, 2014). Akan tetapi, tidak semua informasi dapat disebarkan ke publik melalui press karena media cenderung menyebarkan informasi apabila memiliki news value yang menguntungkan dan menghasilkan banyak pembaca (Miller, 2006). Oleh karena itu, ketimpangan informasi atau yang kita sebut sebagai asimetri informasi diduga masih terjadi di kalangan investor. Asimetri informasi ini bisa menyebabkan kerugian bagi investor jika salah dalam mengambil keputusan investasi.

Adapun upaya yang dapat dilakukan perusahaan untuk menyebarkan informasi perusahaan yaitu melalui website atau media sosial resmi yang dikelola oleh perusahaan tanpa tergantung pada pihak ketiga. Pada portal tersebut, informasi mengenai perusahaan baik yang bersifat keuangan maupun non-keuangan dapat dipublikasikan. Investor dapat mencari informasi dari sejarah perusahaan, produk, bahkan laporan yang ditujukan kepada investor seperti laporan keuangan dan laporan tahunan juga dipublikasikan melalui portal tersebut. Selain itu, perusahaan juga dapat menyebarkan informasi lain kepada investor seperti undangan Rapat Umum Pemegang Saham (RUPS), pembagian deviden, bahkan segala aktivitas 
perusahaan dapat disebarluaskan melalui media ini. Perusahaan tidak lagi menggunakan media konvensional seperti koran atau majalah yang dikendalikan oleh pihak lain di luar perusahaan. Saat ini hampir semua perusahaan telah memiliki website perusahaan karena Otoritas Jasa Keuangan (OJK) untuk menetapkan peraturan tentang keterbukaan informasi kepada semua perusahaan yang terdaftar di Bursa Efek Indonesia.

Dengan adanya teknologi yang memungkinkan perusahaan dapat menyampaikan informasi secara langsung kepada investor melalui media sosial direct-acsess information technologies (DAITs) yang salah satu bentuknya adalah media sosial seperti Facebook dan Twitter, perusahaan akan lebih fleksibel dalam mengungkapkan informasi kepada para pemangku kepentingan. Bagi investor, proses pencarian informasi melalui platform ini diduga dapat mengurangi biaya perolehan informasi seperti waktu, tenaga dan uang karena dapat diakses dengan biaya yang terjangkau. Dengan platform Twitter, perusahaan dapat menyebarkan informasi melalui tweet ke berbagai kalangan investor yang potensial sehingga asimetri informasi berkurang dan likuiditas saham meningkat (Blankespoor, Miller dan White, 2014). Indikasi ini diketahui dari data volume perdagangan serta harga saham yang diminta (bid) dan harga saham yang ditawarkan (offer). Jika terjadi asimetri informasi diantara investor, maka akan terjadi selisih (spread) pada yang besar pada saham tersebut. Sebaliknya, jika spread semakin kecil, maka asimetri informasi diduga semakin berkurang,

Saat ini, saluran media sosial juga sangat populer digunakan oleh perusahaan. Platform ini menyediakan tiga jalur komunikasi yang memungkinkan beberapa pihak terlibat yaitu perusahaan pemilik akun berkomunikasi mengungkapkan informasi melalui tweet di media Twitter atau posting di media Facebook, investor individual mengomunikasikan pendapat melalui komen pada postingan terkait dan komen investor tersebut akan berkomunikasi dengan investor individual lainnya. Dengan adanya efek berantai tersebut, perusahaan akan cenderung mengelola tweet dan posting yang memberikan keuntungan maksimal. Perusahaan diduga memiliki kecenderungan mengeluarkan tweet atau posting tentang good news sesuai dengan strategic behaviour dalam teori sinyal (Jung et al, 2018). Penelitian ini akan akan menggunakan perusahaan yang terdaftar pada Bursa Efek Indonesia dan menggunakan media sosial resmi perusahaan dalam berkomunikasi dengan stakeholder termasuk investor.

Berbagai macam media yang digunakan perusahaan untuk mengungkapkan informasi kepada para investor diharapkan mampu mengurangi asimetri informasi. Namun keefektifan dalam pengelolaannya kadangkala menimbulkan pertanyaan besar apakah benar investor menerima, membaca, mengolah dan menganalisis informasi tersebut dan digunakan untuk mengambil keputusan investasi. Posting dan komen yang terdapat pada platform Facebook dapat membentuk persepsi terutama bagi non-profesional investor (Trinkle et al, 2015). Bahkan perusahaan yang menggunakan sosial media memiliki jalinan yang kuat dengan stakeholders sehingga berdampak pada kinerja perusahaan (Du dan Jiang, 2015).

Penelitian ini bertujuan untuk mendapatkan bukti empiris bahwa penggunaan media sosial dapat menurunkan asimetri informasi. Ada 2 (dua) jenis media sosial yang akan diteliti dalam penelitian ini yaitu Facebook dan Twitter karena masyarakat Indonesia merupakan salah satu pengguna terbesar dari kedua platform tersebut.

Platform media sosial saat ini berperan penting untuk meningkatkan nilai bisnis. Cara komunikasi Perusahaan kepada kepada konsumen dan stakeholders telah mengalami perubahan (Kaplan dan Hein 2010) karena dilakukan melalui berbagai macam platform popular seperti Twitter, Facebook, Youtube, Blog perusahaan yang digunakan untuk pemasaran, pengembangan produk dan hubungan dengan investor. Selain itu, perusahaan juga dapat mengurangi asimetri informasi dengan menyebarkan informasi tentang earnings announcement melalui Twitter (Blankerspoor et al, 2014). Apabila informasi tersebut dapat disebarkan lebih luas kepada investor, melalui business press, maka hal itu juga akan menurunkan spreads (Bushee, Core, Guay dan Hamn, 2010). Selain itu, hasil penelitian pada perusahaan yang tergabung dalam Standar \& Poor's 1500 di US Stock Market menyatakan bahwa perusahaan yang memiliki akun sosial media lebih dihargai oleh pasar dan memiliki kinerja keuangan yang lebih baik (Du dan Jiang 2015).

Pada mulanya, perusahaan menggantungkan penyebaran informasi terkait corporate disclosure melalui perantara informasi seperti press (Bushee dan Miller, 2012), namun jangkauan penyebaran press masih terbatas karena press hanya akan menyebarkan informasi apabila berita menghasilkan banyak pembaca (Miller, 2006). Bagi perusahaan, pengungkapan informasi melalui saluran ini terkendala masalah efisiensi biaya informasi. Biaya yang tinggi menyebabkan jangkauan penyebaran lebih sempit sehinga terjadi asimetri informasi yang dapat menyebabkan adverse selection yang mengakibatkan likuiditas menurun melalui mekanisme proteksi harga saham seperti bid-ask spreads (Leuz dan Wysocki, 2008). Perluasan penyebaran informasi kepada investor melalui media online diduga membantu perusahaan dalam mengurangi isu pemerataan informasi diantara investor, mengurangi asimetri informasi dan meningkatkan likuiditas.

Dalam penyebaran informasi melalui media sosial, kuantitas informasi sangat bergantung kepada pihak perusahaan selaku pemegang akun tersebut. Berdasarkan strategic behaviour, perusahaan akan 
memiliki kecenderungan untuk menyebarkan informasi jika hal itu menguntungkan good news dan cenderung tidak menyebarkan informasi jika berita tersebut tergolong bad news (Jung, 2018). Pada penelitian Curtis, Richardson, dan Schmardebeck (2016) yang berfokus pada aktivitas media sosial (Twitter dan StockTwits) secara keseluruhan selama 30 hari, menemukan bahwa tingkat aktivitas media sosial dikaitkan dengan tingkat kepekaan yang lebih besar terhadap earning surprise, sementara rendahnya aktivitas media sosial dikaitkan dengan pengalihan pengumuman laba yang tidak sesuai ekspektasi atau yang biasa disebut bad news.

Hal ini mendukung teori sinyal yang menyatakan bahwa informasi akuntansi berhubungan dengan pengambilan keputusan investor (Myers, 1989). Laporan keuangan merupakan salah satu bentuk publikasi yang berisi tentang pelaporan kinerja perusahaan yang salah satunya melaporakan tentang earning perusahaan yang menjadi acuan utama para investor sering disebarkan lewat media perusahaan. Pengungkapan ini juga diduga dapat mengurangi asimetri informasi.

Keberadaan direct-acsess information technologies (DAITs) yang berkembang akhir-akhir ini mempengaruhi bagaimana cara komunikasi perusahaan kepada investor sebagai tambahan jalur penyebaran informasi selain perantara informasi seperti press dan dapat berhubungan dengan basis real-time. Bentuk DAITs yang sering digunakan perusahaan adalah media sosial yaitu Facebook dan Twitter. Indonesia merupakan salah satu negara dengan pengguna terbanyak di dunia. Penyebaran informasi yang ideal saat ini adalah melalui penggunaan rilis berita, website perusahaan dan media sosial (Motley, 2011). Dengan bantuan DAITs, perusahaan dapat menyebaran informasi dengan jangkauan yang lebih luas dan biaya yang lebih rendah sehingga diprediksi dapat memitigasi terjadinya asimetri informasi dengan naiknya likuiditas. Berdasarkan uraian tersebut, hipotesis yang dibangun dalam penelitian ini yaitu :

H1: Kepemilikan Facebook resmi perusahaan berpengaruh pada asimetri informasi.

H2 :Kepemilikan Twitter resmi perusahaan berpengaruh pada asimetri informasi.

Dalam melakukan pengujian tersebut, juga dimasukkan variabel lain selain media sosial yang dapat mempengaruhi asimetri informasi seperti volume perdagangan dan ukuran perusahaan. Volume perdagangan merupakan suatu alat untuk melihat reaksi pasar melalui perubahan volume perdagangan di pasar modal. Apabila saham tersebut diperdagangkan secara aktif maka investor tidak perlu memegang saham tersebut terlalu lama. Investor kurang menyukai transaksi saham yang kurang liquid sehingga bisa menurunkan bid-ask spread saham tersebut (Cohen et al, 1981).

Dalam berinvestasi, investor juga mempertimbangkan ukuran perusahaan. Jika perusahaan memiliki aset yang besar, maka perusahaan akan berpotensi menghasilkan kas yang lebih besar di masa mendatang meskipun resiko juga semakin besar. Semakin besar aset diharapkan bidask spread akan menurun.

Adapun persamaan penelitian yang digunakan yaitu:

$$
\begin{gathered}
\text { SPREAD }=\alpha+\beta_{1} \mathrm{FB}_{\mathrm{i}}+\beta_{2} \mathrm{TW}_{\mathrm{i}}+\beta_{3} \mathrm{VOL}_{\mathrm{i}}+ \\
\beta_{4} \mathrm{SIZE}_{\mathrm{i}}+\epsilon
\end{gathered}
$$

\begin{tabular}{|c|c|}
\hline & \\
\hline SPREAD & $=$ Bid-ask Spread \\
\hline$\alpha$ & $=$ Konstan \\
\hline$\beta_{1}, \beta_{2}, \beta_{3}, \beta_{4}$ & $=$ Koefisien \\
\hline FB-i & $=$ Kepemilikan Facebo \\
\hline TW-i & $=$ Kepemilikan Twitter \\
\hline VOL-i & $=$ Volume perdagangan \\
\hline SIZE-i & $=$ Ukuran Perusahaan \\
\hline
\end{tabular}

Keterangan :

\section{METODE PENELITIAN}

\section{Lokasi Studi}

Penelitian ini dilakukan pada perusahaan yang tergolong dalam Consumer Goods Industry yang terdaftar di Bursa Efek Indonesia (BEI). Sektor ini dipilih sebagai sampel karena kemampuan prediksi dari perusahaan yang sebagian besar konsumennya adalah konsumen akan lebih besar dibandingkan konsumen bisnis (Chen et al, 2014). Obyek penelitian pada penelitian ini adalah asimetri informasi yang diperoleh investor publik yang membeli dan menjual saham perusahaan di BEI.

\section{Analisis Data}

Penelitian ini menggunakan metode teknis kuantitatif dengan bantuan alat pengolah data SPSS 25. Asimetri informasi (SPREAD), sebagai variabel dependen dalam penelitian ini diukur dengan menggunakan Bid-Ask Spread, dimana dapat dilihat dari selisih harga pada saat ask dengan harga bid saham perusahaan atau dapat pula selisih harga jual tertinggi dan harga beli terendah saham perusahaan selama kurun waktu satu tahun (Healy,1999). Data mengenai harga saham terendah dan tertinggi diunduh dari laporan statistik perdagangan tahunan dari website BEI www.idx.co.id.

$$
B A S=\frac{\text { ask price }- \text { bid price }}{(\text { ask price }+ \text { bid price }) / 2}
$$

\section{Keterangan:}

BAS (Bid-ask Spread) = selisih harga ask (jual) dengan harga bid (beli) saham perusahaan pada penutupan hari t.

Ask Price = harga ask (jual) tertinggi saham perusahaan saham perusahaan pada penutupan hari $\mathrm{t}$ Bid Price = harga bid (beli) terendah saham perusahaan saham perusahaan pada penutupan hari $t$. 
Media online yang dapat digunakan perusahaan untuk mengungkapkan informasi perusahaan dengan sarana media sosial seperti Facebook (FB) dan Twitter (TW). Kedua platform tersebut dipilih menjadi variabel independen karena Indonesia merupakan salah satu pengguna terbesar di dunia (Septiana, 2018; Clinten, 2019). Keaktifan perusahaan dalam posting dan komentar di sosial media menunjukkan seberapa baik dan transparan manajemen dalam mengelola perusahaan. Informasi yang dapat disajikan perusahaan dapat berupa informasi keuangan maupun non-keuangan. Informasi keuangan meliputi kenaikan penjualan, laba, penambahan proyek dll. Sedangkan informasi non-keuangan seperti produk-produk baru, kegiatan CSR perusahaan, kegiatan sosial perusahaan dll. Melalui sosial media seperti Facebook, berita mampu mempengaruhi persepsi dan reaksi investor ( $\mathrm{Du} \&$ Jiang, 2015).

Selain itu, keduanya memungkinkan perusahaan menyampaikan informasi berupa teks, gambar maupun video. Pengukuran sarana penyebaran informasi melalui Facebook dan Twitter menggunakan variabel dummy, dimana skor 1 akan diberikan pada perusahaan memiliki dan aktif menggunakan Facebook dan Twitter, dan skor 0 jika perusahaan tidak memiliki.

Untuk variabel independen lainnya yang dimaukkan dalam penelitian ini yaitu volume perdagangan (VOL) digunakan proksi Trading Volume Activity (TVA) dimana volume perdagangan saham perusahaan dibagi dengan jumlah total saham yang beredar di Bursa Efek Indonesia. Data ini diambil dari data statistik perdagangan yang diunduh dari www.idx.co.id. Sedangkan untuk data ukuran perusahaan (SIZE) menggunakan data logaritma total aset yang didapat dari laporan keuangan yang telah diunduh.

Adapun jenis data penelitian yang digunakan dalam penelitian ini adalah data kuantitatif meliputi data statistik perdagangan saham perusahaan sampel yang terdaftar di BEI tahun 2018. Sumber data penelitian ini yaitu data sekunder karena sekunder karena data diundur dari situs resmi BEI www.idx.co.id. Populasi dalam penelitian ini adalah perusahaan Consumer Goods Industry yang terdaftar di Bursa Efek Indonesia tahun 2018. Sampel akan diambil dari populasi tersebut menggunakan metode purposive sampling.

Tabel 1. Jumlah Perusahaan Consumer Goods Industry yang Menjadi Sampel Penelitian Berdasarkan Kriteria Pengambilan Sample

\begin{tabular}{llc}
\hline No & Keterangan & Jumlah tahun \\
\hline 1 & Perusahaan Consumer Goods & 39 \\
& Industry yang terdaftar di Bursa \\
& Efek Indonesia tahun 2018 \\
2 & $\begin{array}{l}\text { Perusahaan Consumer Goods } \\
\text { Industry yang tidak aktif di } \\
\text { perdagangan saham }\end{array}$ \\
3 & Data pencilan
\end{tabular}

4 Perusahaan yang memenuhi kriteria 31

\section{HASIL PENELITIAN DAN ANALISIS}

Berikut ini merupakan analisis deskriptif dari data penelitian yang diperoleh berupa variabel Facebook (FB), Twitter (TW), volume perdagangan (VOL), ukuran perusahaan (SIZE) dan bid-ask spread (SPREAD):

Tabel 2. Statistik Deskriptif untuk N = 31

\begin{tabular}{llll}
\hline & Minimum & Maksimum & Rata-rata \\
\hline FB & 0 & 1 & 0,580645 \\
TW & 0 & 1 & 0,387097 \\
VOL & 0,000110 & 1,166131 & 0,116998 \\
SIZE & 2,187521 & 4,984698 & 3,508084 \\
SPREAD & 0,002700 & 0,053911 & 0,019537 \\
\hline
\end{tabular}

Berdasarkan data pada Tabel 2 dapat diambil gambaran bahwa variabel FB dan TW merupakan variabel dummy yang membuktikan adanya keberadaan media sosial perusahaan Facebook atau Twitter dengan skor minimun 0 dan skor maksimum 1. Rata-rata untuk variabel Facebook adalah 0,580645 , sedangkan rata-rata untuk variabel Twitter adalah 0,387097 .

Variabel volume perdagangan menunjukkan bahwa skor minimun yaitu 0,000110 yang diperoleh PT Gudang Garam (GGRM), sedangkan nilai maksimum sebesar 1,166131 diperoleh PT Chitose International (CINT).

Pada variabel ukuran perusahaan, perusahan dengan aset paling minimum dimiliki PT Kedaung Indah Can (KICI) dengan skor 2,187521 dan aset maksimum dimiliki oleh PT Indofood Sukses Makmur (INDF) dengan skor 4,984698.

Bid-ask spread minimum atau perusahaan yang memiliki asimetri informasi terendah dengan skor 0,002700 adalah PT Unilever Indonesia (UNVR). Sedangkan perusahaan dengan bid-ask spread maksimum atau memiliki asimetri tertinggi dengan skor 0,053911 diperoleh oleh PT Pyridam Farma (PYFA).

\section{Uji Asumsi Klasik}

Sebelum melakukan uji hipotesis, terlebih dahulu dilakukan uji asumsi klasik terhadap data yang diujikan. Uji ini terdiri uji normalitas, heteroskedastisitas dan multikolinieritas.

Uji normalitas data dilakukan untuk mengetahui apakah suatu data terdistribusi normal atau tidak. Hasil uji Kolmogorov-Smirnov menyatakan bahwa nilai signifikansi sebesar 0,55 . Hal ini menunjukkan bahwa data terdistribudi normal karena melibihi nilai signifikasi 0,05 atau tingkat kepercayaan 5\%.

Uji heterokedastisitas digunakan untuk mengetahui apakah dalam model tersebut terjadi ketidaksamaan varians dari residu satu pengamatan ke pengamatan yang lain. Hasil uji Glejser menunjukkan bahwa variabel-variabel terbebas dari heteroskedastisitas karena memiliki nilai signifikansi 
lebih dari 5\%. Dengan variabel dependen RES2 berikut ini hasil dari masing-masing variabel :

Tabel 3. Hasil Uji Glejser

\begin{tabular}{lll}
\hline & $\mathrm{t}$ & Sig \\
\hline Konstanta & 2,311699 & 0,028977 \\
FB & $-2,043192$ & 0,051291 \\
TW & $-0,680768$ & 0,502036 \\
VOL & $-1,112286$ & 0,276194 \\
SIZE & $-0,469972$ & 0,642294 \\
\hline Varaber Dependen
\end{tabular}

Variabel Dependen : RES2

Selanjutnya dilakukan uji multikolinieritas yang bertujuan untuk mengetahui apakah dalam model regresi ditemukan adanya korelasi antar variabel indenpenden. Berikut ini merupakah hasil uji multikolinieritas :

Tabel 4. Hasil Uji Multikolinieritas

\begin{tabular}{lll}
\hline & Tolerance & VIF \\
\hline Konstanta & & \\
FB & 0,533645 & 1,873906 \\
TW & 0,379404 & 2,635711 \\
VOL & 0,854420 & 1,170385 \\
SIZE & 0,581074 & 1,720951 \\
\hline
\end{tabular}

Pada hasil pada tabel di atas menunjukkan bahwa nilai VIF kurang dari 10 dan lebih dari 0,01 . Hal ini menyakatan bahwa tidak ada multikolinieritas pada data penelitian.

\section{Uji Hipotesis}

Setelah dilakukan uji asumsi klasik, baru dilaksanakan pengujian hipotesis. Model persamaan ini memiliki koefisien determinasi $\left(\mathrm{R}^{2}\right)$ sebesar $60,4 \%$. Hal ini menunjukkan bahwa variabel-variabel yang ada dalam persamaan ini mampu menjelaskan asimetri informasi sebanyak 60,4\%, sedangkan sisanya merupakan faktor-faktor lain yang tidak dimasukkan dalam variabel penelitian.

Pada penelitian ini, uji hipotesis menggunankan uji regresi berganda. Adapun hasil yang diperoleh pada uji tersebut, disajikan pada tabel berikut ini :

Tabel 5. Hasil Uji Regresi

\begin{tabular}{llll}
\hline & Koefisien & $\mathrm{t}$ & Sig \\
\hline Konstanta & 0,059940 & 5,856941 & 0,000004 \\
FB & $-0,013246$ & 0,004450 & 0,008008 \\
TW & $-0,002176$ & $-3,015165$ & 0,697736 \\
VOL & 0,000031 & $-2,872194$ & 0,996483 \\
SIZE & $-0,009086$ & $-0,392708$ & 0,005673 \\
\hline
\end{tabular}

Berdasarkan hasil uji regresi tersebut, maka didapat persamaan sebagai berikut :

SPREAD $=$ $0,059940-0,013246 \mathrm{FB}-0,002176 \mathrm{TW}+$ 0,000031 VOL $-0,009086$ SIZE $+\epsilon$

Pada variabel Facebook (FB) koefisien dari persamaan regresi menunjukkan arah yang negatif dan signifikan pada nilai 0,008008. Hasil ini menunjukkan bahwa keberadaan Facebook perusahaan yang digunakan untuk mengungkapkan informasi-informasi penting yang berguna bagi pengambil keputusan dapat menurunkan asimetri informasi. Hal ini menandakan bahwa $\mathrm{H} 1$ diterima.

Sedangkan untuk hipotesis $\mathrm{H} 2$ yaitu pengaruh variabel twitter terhadap asimetri informasi ditolak karena tidak signifikan. Namun ada hal yang sesuai prediksi yaitu arah hubungan yang negatif. Untuk variabel independen lainnya yang memiliki pengaruh negatif dan signifikan dengan nilai signifikasinsi 0,005673 adalah ukuran perusahaan. Semakin besar aset yang dimiliki perusahaan ternyata mampu menurunkan asimetri informasi.

\section{KESIMPULAN}

Peran media sosial saat ini bukan hanya menjadi wadah jejaring pertemanaan saja, namun juga sumber untuk mencari informasi. Perusahaan berlomba-lomba untuk menyajikan informasi kepada para investor melalui berbagai macam media. Pengungkapan ini diduga dapat menurunkan asimetri informasi atau ketimpangan informasi yang dialami para investor.

Dalam penelitian ini, informasi yang diangkat adalah informasi yang berhubungan dengan perusahaan baik keuangan maupun non-keuangan. Ada 2 (dua) media sosial yang diuji dalam penelitian ini yaitu Facebook dan Twitter. Berdasarkan hasil analisis deskriptif, diantara kedua platform media sosial Facebook merupakan platform yang lebih sering digunakan oleh responden untuk melakukan pencarian informasi dibandingkan Twitter. Hasil pengujian menunjukkan bahwa Facebook memiliki pengaruh negatif atau dapat menurunkan asimetri informasi. Hasil ini mendukung penelitian dari Du dan Jiang (2015) yang menyatakan bahwa informasi yang diungkapkan perusahaan melalui Facebook dapat mempengaruhi persepsi investor.

Penelitian ini tidak sejalan dengan Blankespoor, Miller dan White (2014) dimana Twitter terbukti secara empiris dapat menurunkan asimetri informasi. Hal ini dikarenakan profil investor di U.S. dan Indonesia berbeda. Di U.S., Twitter digunakan secara aktif untuk memperoleh informasi tentang perusahaan, namun di Indonesia, Twitter masih hanya digunakan untuk posting dan komen aktivitas sehari-hari.

Penelitian ini menambah literatur mengenai peran media sosial yang dimiliki oleh perusahaan dalam mengungkapkan informasi-informasi dalam upaya mengurangi asimetri informasi. Di Indonesia, keberadaan website dan facebook perusahaan masih dipandang penting oleh investor sebagai sarana memperoleh informasi. Meskipun penelitian sejenis belum pernah dilakukan di Indonesia, namun peneliti berharap hasil ini dapat dijadikan motivasi bagi peneliti lain untuk melakukan penelitian 
kontemporer yang mengangkat tentang perkembangan teknologi dalam perannya.

\section{PENGAKUAN}

Riset penulis dibiayai oleh Hibah Penelitian Dosen Pemula dari DRPM DIKTI dengan kontrak No. 110/SP2H/LT/DRPM/2019.

\section{DAFTAR PUSTAKA}

Blankespoor E., Miller, G.S., \& White, H.D. (2014). The Role of Dissemination in Market Liquidity: Evidence from Firms' Use of Twitter. The Accounting Review 89 (1): 79-112.

Bushee, B. J, Core J., Guay, W., \& Hamm, S. (2010). The role of the business press as an information intermediary. Journal of Accounting Research 48 (1): 1-19.

Chen, H., De, P., Hu, Y., \& Hwang, B. (2014). Wisdom of Crowds: The Value of Stock Opinions Transmitted through Social Media. Review of Financial Studies 27 (5): 1367-1403.

Cohen, K., Maier, S., Schwartz, R. \& Whitcomb, D. (1981). Transactions Costs, Order Placement Strategy, and Existence of the Bid-Ask Spread. Journal of Political Economy, 89, 287-305.

Curtis, A., Richardson, V.J., \& Schmardebeck, R. (2016). Social media attention and the pricing of earnings news. In Handbook of Sentiment Analysis in Finance, edited by Mitra, G., and X. Yu. London, U.K.: OptiRisk Systems.

Du, H., \& Jiang, W. (2015). Do Social Media Matters? Initial Empirical Evidence. Journal of Information Systems 29 (2): 51-70.

Drake, M. S., Guest, N. M., \& Twedt, B. J. (2014). The media and mispricing: The role of the business press in the pricing of accounting information. The Accounting Review 89 (5): 1673-1701.
Jung, J.M., Naughton, P.J., Tahoun, A., \& Wang, C. (2018). Do Firms Strategically Disseminate? Evidence from Corporate Use of Social Media. The Accounting Review 93 (4): 225-252.

Kaplan, A. M., \& Haenlein, M. (2010). Users of the world, unite! The challenges and opportunities of social media. Business Horizons 53: 59-68.

Leuz, C., \& Wysocki, P. (2008). Economic Consequences of Financial Reporting and Disclosure Regulation: A Review and Suggestions for Future Research. Working paper, The University of Chicago and University of Miami.

Liu, J. dan Thomas, J. (2000). Stock Returns and Accounting Earnings. Journal of Accounting Research 38, 71-10.

Miller, G. (2006). The press as a watchdog for accounting fraud. Journal of Accounting Research 44 (5): 10011033.

Miller, G. S., \& Skinner, D. J. (2015). The evolving disclosure landscape: How changes in technology, the media, and capital markets are affecting disclosure. Journal of Accounting Research 53 (2): 221-239.

Motley, A. (2011). An individual disclosure decision. IR Update (March 7-10)

Myers, S. (1989). Signaling and Accounting Information. NBER Working Paper Series. Cambridge, Massachusetts.

Stieglitz, S., Mirbabaie, M., Ross, B., \& Neuberger, C. (2018). Social Media Analytics - Challenges in Topic Discovery, Data Collection, and Data Preparation. International Journal of Information Management 39: 156-168.

Verrecchia, R. E. (1983). Discretionary disclosure. Journal of Accounting and Economics 5: 179-194. 